\title{
Effects of wood ash and soil water potential on vegetative development of mung bean (Vigna radiata L.)
}

\author{
Luana Glaup Araujo Dourado ${ }^{1}$, Edna Maria Bonfim-Silva ${ }^{2}$, Tonny José Araújo da Silva ${ }^{2}$, Everton Alves \\ Rodrigues Pinheiro ${ }^{2}$, William Fenner ${ }^{1}$
}

\author{
${ }^{1}$ Faculty of Agronomy and Zootechnic, Federal University of Mato Grosso, Cuiabá, Brazil \\ ${ }^{2}$ Institute of Agricultural and Technological Sciences, Federal University of Mato Grosso, Rondonópolis, \\ Brazil
}

\section{*Corresponding author: embonfim@hotmail.com}

\begin{abstract}
This research aimed to evaluate the amending potential of eucalyptus's wood ash on soil chemical properties and soil-water potential. The experiment was conducted in a greenhouse at the Federal University of Mato Grosso, campus in Rondonópolis. The experimental design was composed of randomized blocks in a $5 \times 5$ factorial scheme, including five soil-water potentials $(-4,-8,-16$, -32 and $-64 \mathrm{kPa}$ ), and five wood ash doses $\left(0 ; 8 ; 16 ; 24\right.$ and $\left.32 \mathrm{~g} \mathrm{dm}^{-3}\right)$. The soil samples were collected from the top layer of an Oxisol under natural Cerrado vegetation. Mung bean (Vigna radiata L.) growth variables (plant height, numbers of leaves, stem diameter, and SPAD index) were analyzed at three different phenological periods. In general, the wood ash doses increased soil pH, eliminated the exchangeable aluminum, and improved soil essential nutrients availability. As a result, mung bean plants responded positively to wood ash, achieving superior results at doses ranging from 24 to $26 \mathrm{~g} \mathrm{dm}^{-3}$. The interaction between wood ash doses and soil water potential was not significant. However, drier soil conditions constrained plant growth severely. According to our experimental conditions, plant growth variables achieved higher performance at soil water potential of $-4 \mathrm{kPa}$.
\end{abstract}

Keywords: Biomass ash, Brazilian Cerrado, drought stress, matric potential plant nutrition.

Abbreviations: DAE_days after the emergency; DAS_day after sowing.

\section{Introduction}

The recent population growth of the last decades indicates that by the end of this century the number of inhabitants will be approximately 11 billion. Consequently, this population growth will demand higher food production, pressuring the current agricultural systems to increase yield in a relatively reduced time window (Ray et al., 2013). Besides the global limitations related to the expansion of agricultural frontiers, climate change is expected to reduce the availability of natural resources, while intensifies abiotic and biotic stress on cropping systems (Challinor et al., 2016; Zhao et al., 2017; Pandey et al., 2017). Thus, it is necessary to align higher agricultural yields with the optimization of natural resources demand (e.g., adequate supply of water and nutrients during the phenological cycles of crops).

Brazil is one of the world's largest producers of agricultural commodities (Strassburg et al., 2014), contributing significantly to the food demand from several countries. The importance of Brazilian agriculture becomes even more relevant when it comes to grain production, where the Cerrado region stands out. Although this region is characterized by irregularities in rainfall patterns and for soils with high acidity (and reduced nutrient availability), but it is one of the largest world's grain producers due to the adoption of great quantities of agricultural inputs (Rada, 2013). The low pH reduces the availability of several essential nutrients in the soil, such as phosphorus, potassium, calcium, and magnesium, which become partially available when acidity is amended (Bonfim-Silva et al., 2018; Pantano et al., 2016).

Given the need for this large amount of agricultural inputs (correctives and nutrients) in the soils of the Brazilian Cerrado, a sustainable proposal might be consisted of the adoption of agroindustrial residues as potential sources of corrective and nutrients, especially for those small-scale cropping systems. Potential agro-industrial residues include the wood ash (Zimmermann, 2002; Santos et al., 2014), which is a material with high neutralizing capacity and appreciable amounts of essential nutrients. In addition to the positive aspects related to soil chemistry, wood ash may also improve soil hydraulic properties (Ram and Masto, 2004; Stoof et al., 2010), especially in retention and hydraulic conductivity, which are closely related to soil water availability to plant transpiration (Hansen et al., 2018; Maresca et al., 2017; Symanowicz et al., 2018; Pereira et al., 2016).

Among the many cropping systems in the Cerrado region that could benefit from wood ash, the green mung bean (Vigna radiata L.) is one of the most important one. Due to its short growing cycle, mung bean is an alternative crop for the Autumn-Winter growing season (off-season) and as the 
main crop during the regular growing season for small producers. Mung bean is an excellent $\mathrm{N}_{2}$ fixer, allowing nutrient cycling, nitrogen addition, and the increasing of soil organic matter content. In addition to the benefits to the following crop (when cropped off-season), the mung bean grain is nutritionally rich in digestive protein (25-28\%), making this plant species extensively cultivated in tropical and subtropical regions (Kumar et al., 2013).

The wood ash has shown potential to amend soil $\mathrm{pH}$, and consequently increase in availability of nutrients in the soil. This research aimed to evaluate this agro-industrial residue to alter the soil chemical properties under different values of soil water potential. The experimental setup comprised of mung bean plants grown on designed pots under different doses of wood ash and controlled ranges of soil water content. Mung bean was selected due to its relevant presence among small-scale grain producers, representing a plausible cultivation system suitable for future adoptions of wood ash as an alternative material for soil chemical amendment.

\section{Results and discussion}

\section{Soil chemical analysis at the end of the experiment}

The chemical analysis of composite soil samples at the end of the experimental period showed that wood ash doses promoted soil $\mathrm{pH}$ by increasing the total elimination of exchangeable Al at the dose of $24 \mathrm{~g} \mathrm{dm}^{-3}$. Soil organic matter together with $\mathrm{P}, \mathrm{K}, \mathrm{Ca}$ and $\mathrm{Mg}$ availability, CEC, and base saturation responded positively to the wood ash doses as well (Table 1).

The increase in soil $\mathrm{pH}$ can be mainly attributed to the alkaline property of the wood ash, thus neutralizing soil acidity by the reactions of calcium carbonates (main wood ash component), potassium and magnesium (Etiégni and Campbell, 1991; Ohno, 1992; Erich and Ohno, 1992; Foletto et al., 2005; Ingerslev et al., 2014; Freire et al., 2015). Oxides and hydroxides are also components of wood ash (Hansen et al., 2017; Cruz-Paredes et al., 2017).

Higher soil phosphorus content upon increase in wood ash doses is partly explained by the high content of this element in the wood ash material (Table 6). Furthermore, increase in $\mathrm{pH}$ may enhance the natural availability of phosphorus (Donega, 2011; Prado et al., 2002). Likewise, the increased availability of potassium, calcium, and magnesium was also promoted by the appreciable concentration of these elements in the wood ash, and the higher $\mathrm{pH}$ values may also have contributed to the greater availability of these nutrients in the soil (Donega, 2011; Prado et al., 2002; Park et al., 2012).

\section{Effect of wood ash on growth variables}

The wood ash and soil-water potential significantly affected the analyzed growth variables $(p<0.001)$. However, the effects were isolated. There was no interaction between wood ash doses and soil-water potentials. Therefore, the results regarding these treatment groups will be presented and discussed separately.

Response of plant height, number of leaves and stem diameter of mung bean plants to wood ash doses was fitted to the quadratic regression model (Table 2) for the three evaluation periods $(15,30$ and $45 \mathrm{DAE}$ ) (Figures $1 \mathrm{~A}, 1 \mathrm{~B}$ and $1 C)$. The maximum plant heights $(11.3,17.3$, and $20.8 \mathrm{~cm})$ were observed at wood ash doses of $27,24.8$, and $25.3 \mathrm{~g} \mathrm{dm}^{-}$
${ }^{3}$ for the three evaluation periods, respectively. The number of leaves significantly responded to wood ash doses, with the highest values at doses ranged from 24 to $26 \mathrm{~g} \mathrm{dm}^{-3}$. The highest stem diameter was observed at doses of 23,22 , and $24 \mathrm{~g} \mathrm{dm}^{-3}$ for the three evaluation periods, respectively.

Regarding the leaf chlorophyll index, the SPAD index behaved linearly with the wood ash doses for the first evaluation period (15 DAE) and quadratic for the other evaluation periods ( 30 and $45 \mathrm{DAE}$ ) (Table 2). At $15 \mathrm{DAE}$, the SPAD index was increased by $13.3 \%$ at the highest wood ash dose $\left(32 \mathrm{~g} \mathrm{dm}^{-3}\right)$ as compared to the control treatment. For the second and third evaluation period, the highest chlorophyll index (53.5 and 53.4) was occurred at doses 28 and $25 \mathrm{~g} \mathrm{dm}^{-3}$, respectively (Figure 1D).

According to Table 1, the wood ash used in this research showed the appreciable amount of macronutrients in its composition ( $\mathrm{Ca}, \mathrm{Mg}, \mathrm{P}$ and $\mathrm{K}$ ), thus acting as a promoter of plant growth. Symanowicz et al. (2018) showed that wood ash residue can be undoubtedly considered a source of macronutrients to plants, therefore, prone to adoption in cropping systems. Dallago (2000) observed that wood ash influences the vegetative growth and development of plants, whereas either the lack or the excess of wood ash significantly reduce the plant height. This indicates the need for studies to find the correct balance between wood ash dose and plant metabolism. Bonfim-Silva et al. (2017), evaluated the potential of ash on leguminous plants. They found that vegetative growth may be limited when doses are not within the optimal range for plant phenological development.

The response of the number of leaves to wood ash doses indicates the positive effect of this residue on the initial formation and expansion of leaves, stimulated by the increase of phosphorus and calcium availability in the soil solution. In addition to the aboveground variables, the wood ash also triggered the root system development (Figure 2).

In general, phosphorus has a diverse effect on metabolism of plant tissues. It plays a paramount role in chemical reactions related to energy transfer between cells, respiration and photosynthesis. Restricted phosphorus availability in the early phenological stages of the crop may result in severe plant growth reduction (Malavolta, 1989; Grant et al., 2001). According to Arf (1994), although phosphorus is added to the soil in appreciable quantities, it is still the most limiting nutrient in common bean production in most of the Brazilian soils, mainly due to its immobilization by the adsorption processes, precipitation or conversion into organic forms (Holford, 1997). According to Fageria et al. (2003), the influence of phosphorus on the bean crop is notorious, acting on the increase of shoot biomass production, with a positive effect on the number of pods and grain yield. Besides the element $\mathrm{P}$, other elements such as $\mathrm{S}, \mathrm{Ca}$ and $\mathrm{Mg}$ are essential for the constitution of structural elements of the plant (e.g. cell walls), promoting a balanced plant growth (Figure 2), allowing above and belowground development traits related to lodging resistance, facilitating the harvesting process (Carneiro, 1995; Bonfim-Silva et al., 2016).

The SPAD index indirectly represents the leaf chlorophyll content, which in turn, is highly correlated to plant nitrogen nutritional status (Costa, et al., 2008; Schlichting et al., 2015). In addition to the relationship between the SPAD index and the plant nutritional status regarding the nitrogen, it also allows inferring on chlorophyll-related metabolic processes (Markwell et al., 1995; Guimarães et al., 1999). 
Table 1. Average values of soil chemical composition subjected to wood ash doses.

\begin{tabular}{|c|c|c|c|c|c|c|c|c|c|}
\hline Dose & $\mathrm{pH}$ & $\mathrm{P}$ & $\mathrm{K}$ & $\mathrm{Ca}$ & $\mathrm{Mg}$ & $\mathrm{Al}$ & CEC & O.M. & $\mathrm{V}$ \\
\hline $\mathrm{g} \mathrm{dm}^{-3}$ & $\left(\mathrm{CaCl}_{2}\right)$ & \multicolumn{2}{|c|}{$m g d^{3}$} & \multicolumn{2}{|c|}{ cmolc dm $\mathrm{dm}^{-3}$} & & & $\mathrm{~g} \mathrm{dm}^{-3}$ & $\%$ \\
\hline 0 & 3.98 & 3.78 & 79.91 & 0.48 & 0.24 & 0.86 & 7.26 & 26.46 & 12.79 \\
\hline 8 & 4.40 & 7.98 & 116.65 & 1.19 & 0.49 & 0.54 & 7.58 & 28.43 & 26.16 \\
\hline 16 & 4.72 & 19.27 & 170.59 & 1.63 & 0.65 & 0.18 & 7.52 & 28.59 & 36.30 \\
\hline 24 & 5.20 & 37.43 & 372.18 & 2.47 & 0.97 & 0.00 & 8.74 & 32.77 & 50.00 \\
\hline 32 & 5.39 & 44.89 & 300.53 & 2.79 & 1.07 & 0.00 & 8.43 & 32.62 & 54.79 \\
\hline
\end{tabular}

Dose = wood ash; $\mathrm{P}=$ Phosphorus; $\mathrm{K}=$ Potassium; $\mathrm{Ca}=$ Calcium; $\mathrm{Mg}=$ Magnesium; $\mathrm{Al}=$ Aluminum; $\mathrm{OM}=$ Organic matter; $\mathrm{CEC}=$ Cations Exchange Capacity at $\mathrm{pH} 7.0 ; \mathrm{V}=$ Base saturation.
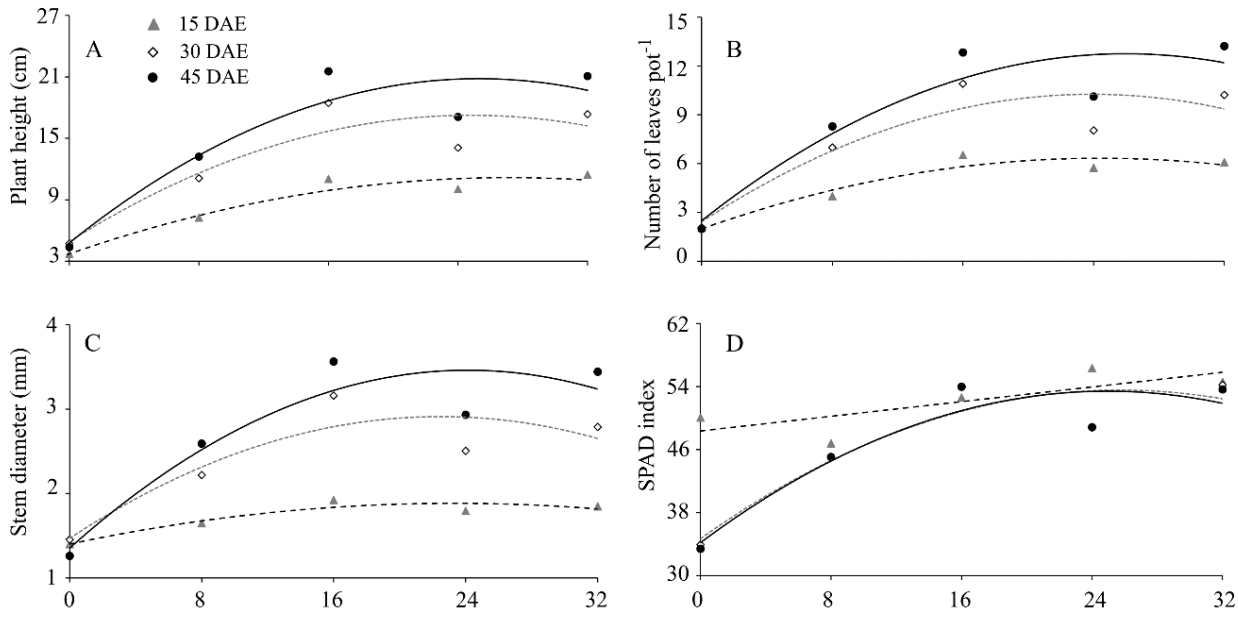

Figure 1. Plant height (A), number of leaves (B), stem diameter (C), and SPAD index (D) of mung bean plants at 15, 30, and 45 DAE subjected to wood ash doses $(p<0.001)$.

Table 2. Fitted regression equations describing mung bean growth variables response to wood ash doses $\left(\mathrm{g} \mathrm{dm}^{-3}\right)$

\begin{tabular}{|c|c|c|c|}
\hline \multirow{2}{*}{ Variable } & \multicolumn{3}{|c|}{ Fitted equation } \\
\hline & $15 \mathrm{DAE}$ & $30 \mathrm{DAE}$ & $45 \mathrm{DAE}$ \\
\hline \multirow{2}{*}{ Plant height [cm] } & $-0.01 \omega^{2}+0.55 \omega+3.73$ & $-0.02 \omega^{2}+0.99 \omega+4.92$ & $-0.03 \omega^{2}+1.27 \omega+4.78$ \\
\hline & $R^{2}=0.94$ & $R^{2}=0.84$ & $R^{2}=0.88$ \\
\hline \multirow{2}{*}{ Number of leaves [-] } & $-0.007 \omega^{2}+0.36 \omega+2.0$ & $-0.01 \omega^{2}+0.66 \omega+2.43$ & $-0.02 \omega^{2}+0.79 \omega+2.49$ \\
\hline & $R^{2}=0.93$ & $R^{2}=0.83$ & $R^{2}=0.87$ \\
\hline \multirow{2}{*}{ Stem diameter $[\mathrm{mm}]$} & $-0.001 \omega^{2}+0.04 \omega+1.4$ & $-0.003 \omega^{2}+0.13 \omega+1.47$ & $-0.004 \omega^{2}+0.17 \omega+1.35$ \\
\hline & $R^{2}=0.90$ & $R^{2}=0.81$ & $R^{2}=0.87$ \\
\hline \multirow{2}{*}{ SPAD index [-] } & $0.23 \omega^{2}+48.37$ & $-0.03 \omega^{2}+1.47 \omega+34.7$ & $-0.03 \omega^{2}+1.54 \omega+34.2$ \\
\hline & $R^{2}=0.61$ & $R^{2}=0.87$ & $R^{2}=0.88$ \\
\hline
\end{tabular}

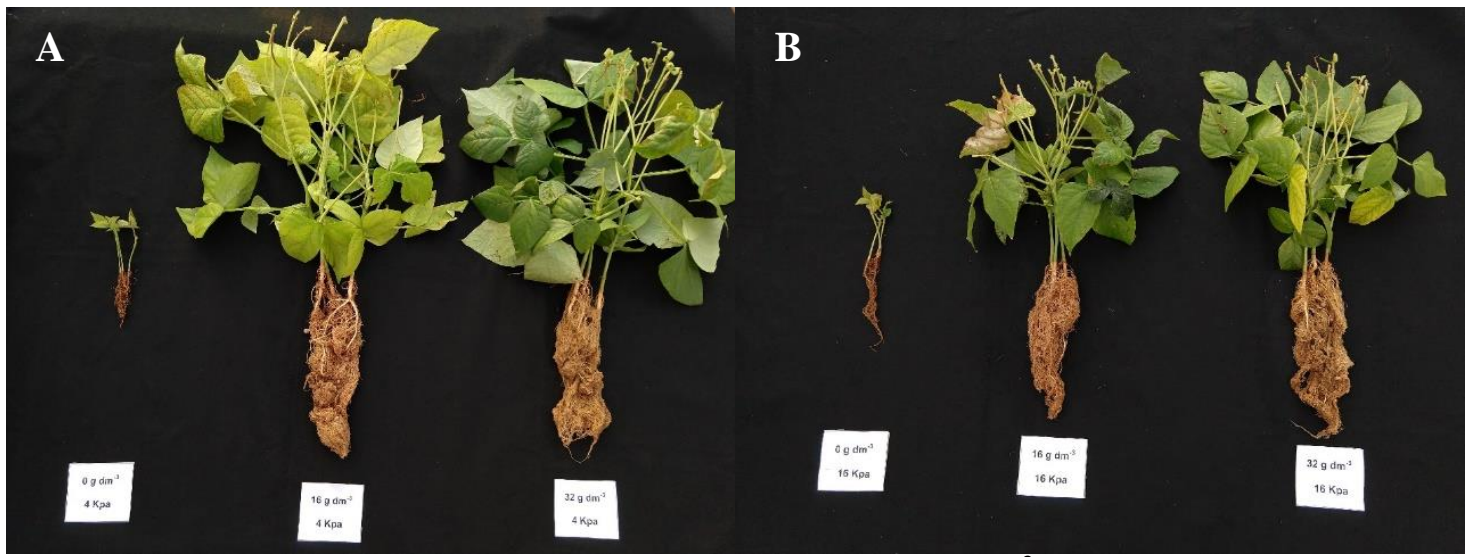

Figure 2. Development of mung bean plants under wood ash doses $\left(0,16\right.$, and $\left.32 \mathrm{~g} \mathrm{dm}^{-3}\right)$ under two values of soil-water potential, $-4 \mathrm{kPa}(\mathrm{A})$ and $-16 \mathrm{kPa}(\mathrm{B})$. 
Table 3. Fitted regression equations describing the mung bean growth variables response to soil-water potential $|\mathrm{h}|$.

\begin{tabular}{lccc}
\hline \multirow{2}{*}{ Variable } & \multicolumn{3}{c}{ Fitted equation } \\
\cline { 2 - 4 } Plant height [cm] & $-0.09|h|+11$ & $-0.20|h|+18.2$ & $45 \mathrm{DAE}$ \\
\hline Number of leaves [-] & $R^{2}=0.84$ & $R^{2}=0.76$ & $-0.29|h|+22.61$ \\
& $-0.05|h|+6.23$ & $-0.12|h|+10.72$ & $R^{2}=0.81$ \\
Stem diameter [mm] & $R^{2}=0.70$ & $R^{2}=0.71$ & $-0.16|h|+13.23$ \\
& $-0.01|h|+1.91$ & $-0.03|h|+3.16$ & $R^{2}=0.76$ \\
SPAD index [-] & $R^{2}=0.85$ & $R^{2}=0.78$ & $-0.04|h|+3.87$ \\
& $N S^{*}$ & $-0.37|h|+56.47$ & $R^{2}=0.81$ \\
& & $R^{2}=0.70$ & $-0.36|h|+56.01$ \\
\hline
\end{tabular}

*NS: not significant.
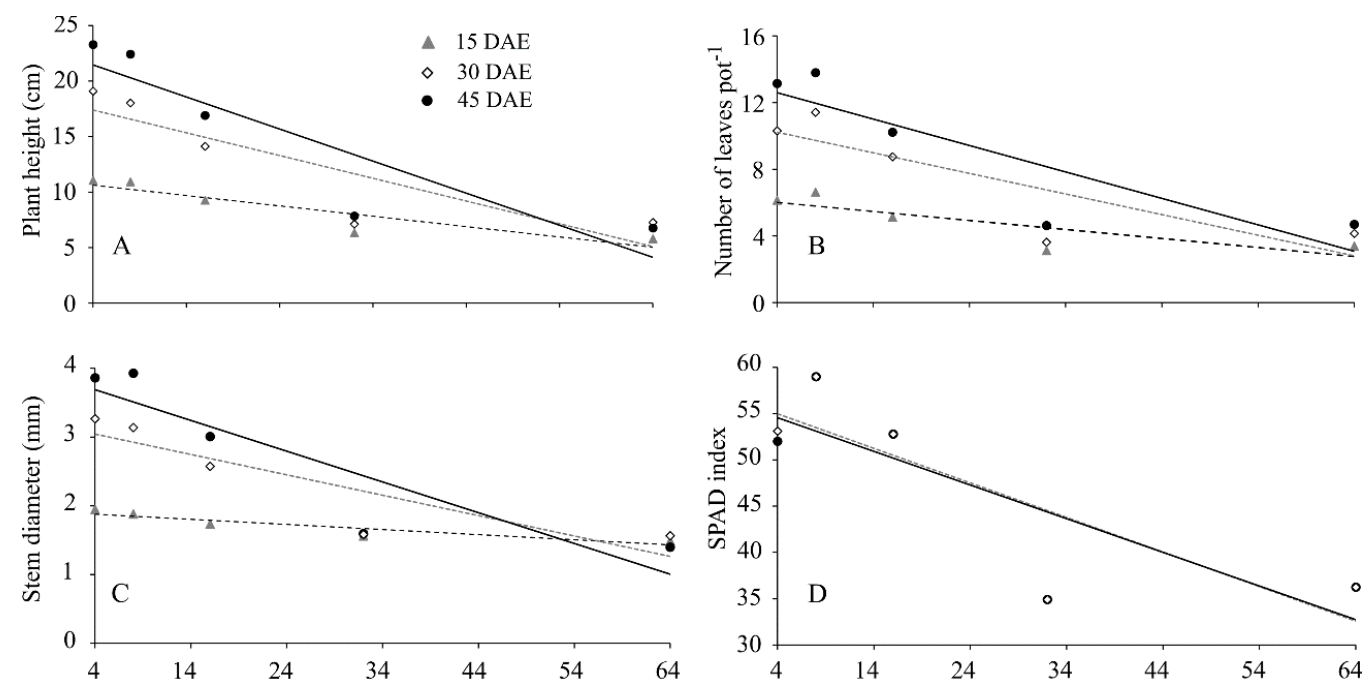

Figure 3. Plant height (A), number of leaves (B), stem diameter (C), and Chlorophyll Index (SPAD) (D) of mung bean plants for decreasing values of soil-water potential at 15,30 and 45 DAE $(p<0.001)$.

Table 4. Treatments consisting of the 13 combinations of wood ash doses and soil-water potential according to the experimental design 'modified central composite' of Littell and Mott (1975).

\begin{tabular}{ll}
\hline Wood ash dose $\left(\mathrm{g} \mathrm{dm}^{-3}\right)$ & Soil-water potential $(\mathrm{kPa})$ \\
\hline 0 & $-4 ;-16 ;-64$ \\
8 & $-8 ;-32$ \\
16 & $-4 ;-16 ;-64$ \\
24 & $-8 ;-32$ \\
32 & $-4 ;-16 ;-64$ \\
\hline
\end{tabular}

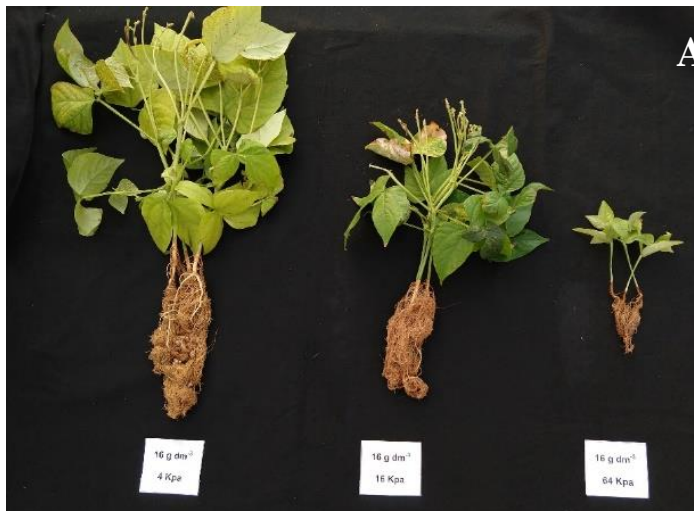

A

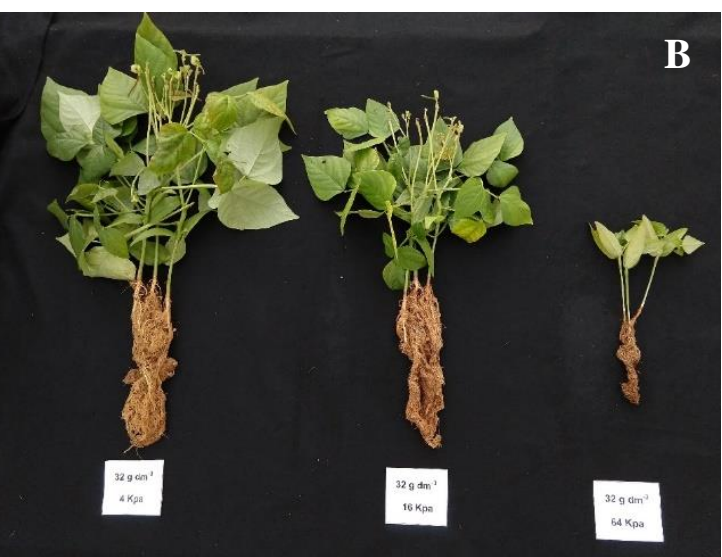

Figure 4. Mung bean plants under the wood ash doses of $16 \mathrm{~g} \mathrm{dm}^{-3}(\mathrm{~A})$ and $32 \mathrm{~g} \mathrm{dm}^{-3}(\mathrm{~B})$ and soil-water potential ranging from -4, 16 , and $-64 \mathrm{kPa}$, respectively. 
Table 5. Chemical and particle size analysis for the top layer of the sampled Oxisol after collection.

\begin{tabular}{|c|c|c|c|c|c|c|c|c|c|c|c|c|}
\hline $\begin{array}{l}\mathbf{p H} \\
\mathrm{CaCl}_{2}\end{array}$ & & & $\mathrm{Ca}$ & $\begin{array}{r}\mathbf{M g} \\
\mathrm{cm}\end{array}$ & $\begin{array}{c}\text { Al } \\
\mathrm{dm}^{-3}\end{array}$ & $\mathbf{H}$ & CEC & $\begin{array}{l}\text { OM } \\
\text { g kg }^{-1}\end{array}$ & $\begin{array}{l}\mathbf{V} \\
\% \\
\end{array}$ & $\begin{array}{l}\text { Sand } \\
\mathrm{g} \mathrm{kg}^{-1}\end{array}$ & Silt & Clay \\
\hline 4.0 & 1 & 43 & 0.5 & 0.3 & 1.2 & 4.7 & 8.3 & 29 & 11 & 507 & 116 & 377 \\
\hline
\end{tabular}

$\mathrm{P}=$ Phosphorus; $\mathrm{K}=$ Potassium; $\mathrm{Ca}=$ Calcium; $\mathrm{Mg}=$ Magnesium; $\mathrm{Al}=$ Aluminum; $\mathrm{H}=$ Hydrogen; $\mathrm{CEC}=$ Cation Exchange Capacity at $\mathrm{pH}$ 7.0; $\mathrm{OM}=$ Organic matter; $\mathrm{V}=$ Base saturation.

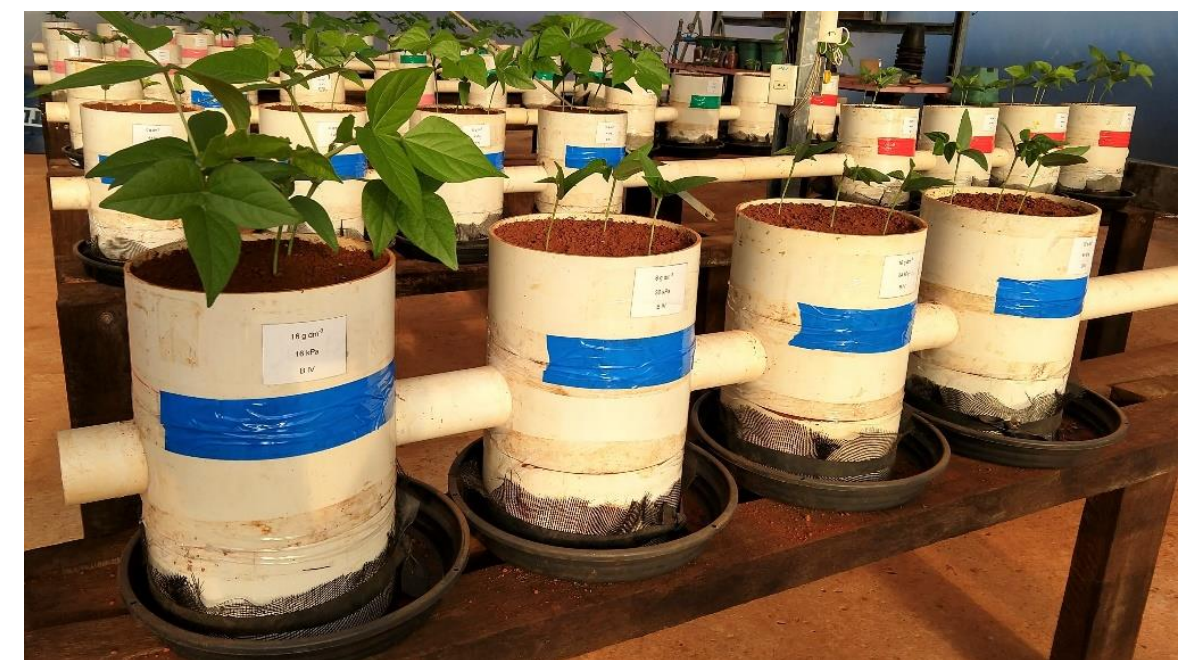

Figure 5. Experimental units coupled with a horizontal tube to allow soil water content measurements by a Diviner capacitance probe during the experimental period.

Table 6. Chemical composition of the eucalyptus wood ash used in this research.

\begin{tabular}{|c|c|c|c|c|c|c|c|c|c|c|c|c|c|}
\hline $\begin{array}{l}\mathbf{p H} \\
\mathrm{CaCl}_{2}\end{array}$ & $\mathbf{N}$ & $\mathrm{P}_{2} \mathrm{O}_{5}$ & $\mathrm{~K}_{2} \mathrm{O}$ & $\mathrm{Ca}$ & $\begin{array}{r}\mathrm{Mg} \\
\mathrm{g} \mathrm{kg}^{-1}\end{array}$ & $\mathrm{Na}$ & $\mathrm{SO}_{4}$ & $\mathbf{S i}$ & $\mathrm{Fe}$ & $\mathrm{Cu}$ & $M n$ & B & $\mathrm{Zn}$ \\
\hline 10.7 & 3.1 & 9.6 & 34.7 & 33.0 & 21.0 & 0.12 & 2.0 & 274.4 & $\begin{array}{l}10 . \\
3\end{array}$ & 0.0 & 0.4 & 0.1 & 0.1 \\
\hline
\end{tabular}

$\mathrm{N}=$ Nitrogen; $\mathrm{P}_{2} \mathrm{O}_{5}=$ Phosphorus in neutral ammonium citrate and water $(\mathrm{CNA}+$ water $) ; \mathrm{K}_{2} \mathrm{O}=$ Potassium; Ca = Calcium; $\mathrm{Mg}=\mathrm{Magnesium} ; \mathrm{Na}=$ Sodium; $\mathrm{SO}_{4}=$ Sulfur; $\mathrm{Si}=$ Silicon; $\mathrm{Fe}=$ Iron; $\mathrm{Cu}=$ Cupper total; $\mathrm{Mn}=$ Manganese Total; $\mathrm{B}=$ Boron Total; $\mathrm{Zn}=\mathrm{Zinc}$ Total.

As no nitrogen fertilizer was applied in this experiment, it can be presumed that plant nitrogen nutrition occurred essentially from the biological nitrogen fixation process, which was probably positively influenced by the wood ash doses (Figure 1D). In acidic soils, the biological fixation of $\mathrm{N}_{2}$, and consequently the growth and development of leguminous plants are affected by several factors such as the low availability of phosphorus and calcium in the soil and the toxicity of aluminum that acts restraining the nodulation processes (Andrew, 1976; Murphy et al., 1984). Silva et al. (2010) verified positive correlations between nodulation and chlorophyll index in cowpea leaf, indicating that biological nitrogen fixation through nodulation may significantly influence the relationship between chlorophyll index and leaf $\mathrm{N}$ concentration. As the process of biological fixation of $\mathrm{N}_{2}$ requires a considerable amount of energy, a healthy host plant is essential, demanding phosphorus for the cellular energy exchange processes (Chaudhary and Fujita, 1998; Sa and Israel, 1991; Campo and Hungria, 2002).

Effect of soil-water tension on mung bean growth variables The analyzed variables (plant height, number of leaves, stem diameter, and SPAD index) behaved linearly to soil-water potential for the three evaluation periods $(15,39$, and 45 DAE) (Figure 3 and Table 3). The highest values of these variables were occurred at soil-water potential of $-4 \mathrm{kPa}$, with considerable reduction as the soil becomes drier. Regarding the effect of the soil-water pressure on the SPAD index, we observed that the numerical differences were not significant $(p>0.05)$ for the first evaluation period at 15 DAE. On the other hand, the chlorophyll index fitted to linear regression models at 30 and 45 DAE (Figure 3D), being significantly decreased at drier soil conditions.

According to Freitas et al. (2011) and Nezami et al. (2008), the reduction in plant growth is one of the main stress symptoms of water deficit, reducing cell turgidity and negatively affecting cell differentiation, expansion, and elongation (Cairo, 1995; Nogueira et al., 2005). These effects were observed for the treatments under the condition of more negative values of soil-water potential (lower plant heights, reduced number of leaves, thinner stems and lower SPAD index), which probably negatively affect the production and translocation of carbohydrates in the plant (Ludlow and Muchow, 1990; Larcher, 2004).

Soil water availability favors the root extraction process, promoting nutrient translocation as well as cell growth (Pereira et al., 2016). According to Figure 4, as the drier soil condition persists, root and aboveground biomass are greatly reduced.

The observed lower number of leaves in plants subjected to lower soil moisture may occur due to a physiological response mechanism to water deficit to reduce water loss by transpiration (Floss, 2004; Mahajan and Tuteja, 2005; Inman-Bamber et al., 2008). Similar to the results of this research, other studies have observed better performance 
of growth and yield variables under wetter soil conditions (Sangakkara, 1999; Sengupta, 2013; Das, 2017).

Usually, the soil-water potential of $-4 \mathrm{kPa}$ is relatively high for a tropical Oxisol. This indicates possible stress due to excess water in this particular Oxisol coarse-textured with sand content of $>50 \%$ (Table 5). Therefore, there is sufficient aeration porosity to meet the respiratory needs of the crop at $-4 \mathrm{kPa}$. The Chlorophyll index tends to be lower in plants under water excess due to the increased concentration of free radicals that disintegrate the chlorophyll molecule (Drew, 1997). However, in the present study, the SPAD index was higher at $-4 \mathrm{kPa}$, which is another indication that stress due to water excess did not occur at this particular soil-water pressure head. Similar to the results of the present study, Sangakkara (1999) showed a reduction in the chlorophyll index of mung bean and cowpea at drier soil conditions.

As shown by this research and other studies cited throughout this manuscript, wood ash has the potential to alter the chemical properties of the soil, and thereby promote plant growth. On the other hand, the hypothesis of its positive effect on soil physical properties is based on static indices, e.g. organic matter content, soil porosity and water retention in some potentials values (Karmakar et al., 2009; Conceição et al., 2005; Islabão et al., 2016). Conversely, to verify this hypothesis a mechanistic evaluation tool is required that allows dynamic analysis of the main variables that control the physical processes of water transfer in the vadose zone (Bonfante et al., 2019; Pinheiro et al., 2019). In this study, there was no interaction between wood ash doses and soil-water potentials, which is an expected result, since changes on soil hydraulic properties may require a much longer time period than the one experienced in this research. Possibly, such analysis would be more conclusive in an experiment under a condition where the natural soil structure is preserved.

\section{Materials and methods}

\section{Geographic location and experimental characterization}

The experiment was carried out from February to June 2019 in a greenhouse at the Federal University of Mato Grosso, campus in Rondonópolis, located at latitude 16 $28^{\prime} \mathrm{S}$, longitude 540 35' W, and $284 \mathrm{~m}$ above sea level. The regional climate type according to Köppen classification is Aw, tropical zone with dry winter and wet summer. The average temperature and relative humidity during the experiment were $27.1^{\circ} \mathrm{C}$ and $53.8 \%$, respectively.

The statistical design used in this research was composed of randomized blocks in a $5^{2}$ fractional factorial design, consisting of five doses of wood ash $(0,8,16,24$ and $\left.32 \mathrm{~g} \mathrm{dm}^{-3}\right)$ and five potential $(h)$ values $(-4,-8,-16,-32$ and $-64 \mathrm{kPa}$ ) with four replicates. The number of experimental units (52) was established according to the experimental design based on the modified central composite (Littell and Mott, 1975), consisting of 13 treatments (combinations of wood ash doses, $\mathrm{g} \mathrm{dm}^{-3}$, and soil-water potential, $\mathrm{kPa}$ ) (Table 4).

Experimental units were composed of adapted pots, especially built for this research. Three individual PVC rings (10 cm high and $20 \mathrm{~cm}$ diameter each) were assembled on the top of each other, totaling a $30 \mathrm{~cm}$ height pot. In the middle PVC ring, a horizontal $5-\mathrm{cm}$ diameter perforation allowed coupling four experimental units by inserting a tube $150-\mathrm{cm}$ long (Figure 5). Through this horizontal tube, soil water content was periodically monitored by a capacitance probe (Diviner $2000^{\circledR}$ ). Discounting the volume occupied by this horizontal tube, each experimental unit presented a volume of $8.7 \mathrm{dm}^{3}$.

\section{Soil collection, analysis and correction}

The soil material used in this experiment was collected from the top layer (0.0-0.2 $\mathrm{m}$ ) of an Oxisol (Soil Taxonomy) under natural Cerrado vegetation. The material used to fill the pots passed through a $4 \mathrm{~mm}$ sieve. Additional soil samples passed through a $2 \mathrm{~mm}$ sieve for chemical and particle size characterization (Table 5) according to the methodology proposed by Embrapa (2017).

Wood ash doses $\left(0,8,16,24\right.$, and $\left.32 \mathrm{~g} \mathrm{dm}^{-3}\right)$ were used as soil $\mathrm{pH}$ amendment. Soil material and the respective wood ash doses were mixed in proper plastic bags. After the homogenization (soil material and wood ash), the mixture material was used to fill the experimental units (pots). The soil-water potential of the accommodated material in each experimental unit was maintained according to each treatment $(-4,-8,-16,-32$, and $-64 \mathrm{kPa})$. To allow soil acidity reduction by chemical reactions, experimental units with the mixed material remained in repose for 30 days under the respective water tension in the soil, according to each treatment (Table 4).

The wood ash used in this research prepared from the combustion of wood materials in local industrial plants for power generation. The chemical composition of the used ash is shown in Table 6.

\section{Fertilization and irrigation management}

After incubation period of 30 days, ten seeds of mung bean (Vigna radiata L.) were sown four centimeters deep in each experimental unit. Seedling thinning was performed on the sixth and the twelfth day after sowing (DAS). The final plant population was established in three vigorous plants per each pot unit.

Irrigation was controlled by measuring soil water content using a calibrated capacitance probe (Diviner $2000^{\circ}$ ). The functional relationship between soil-water potential and soil water content $(h$-圆) of the accommodated soil material was previously established to similar pots designs. Water replenishment was performed manually using a graduated container to maintain the soil-water potential according to the values established for each treatment.

The response variables analysis were performed at 15,30 and 45 DAE: Plant height [cm]; the number of leaves [-] per experimental unit; average stem diameter [mm] per experimental unit at $2 \mathrm{~cm}$ from the soil surface; and chlorophyll index by SPAD meter-502, obtained from the average of five readings taken on random leaves in the middle third of the plants. After the experiment completion, a composite soil sample corresponding to each wood ash dose was subjected to chemical analysis.

\section{Statistical analysis}

The response variables were analyzed by the statistical software SISVAR (Ferreira, 2011), testing the interaction between the treatments (wood ash doses $x$ soil-water potentials) followed by the analysis of variance and regression test at $p<0.05$.

\section{Conclusions}

The main findings of our experimental research on evaluating the combined effects of wood ash dose and soil- 
water potentials on growth variables of mung bean allowed us to conclude that: Plant height, the number of leaves, stem diameter and chlorophyll index are significantly and independently influenced by wood ash doses and soil water stress. Fertilization with wood ash with doses between 24 and $26 \mathrm{~g} \mathrm{dm}^{-3}$ allowed the best responses for the analyzed variables related to the development of mung bean crop. The analyzed growth variables achieved higher performance at a soil-water potential of $-4 \mathrm{kPa}$, indicating that although being a rustic crop, the mung bean grows more efficiently under higher soil water availability.

\section{References}

Andrew CS (1976) Effect of calcium, pH and nitrogen on the growth and chemical composition of some tropical and temperate legumes: I., nodulation and growth. Aust J Agric Res. 27: 611-623.

Arf O (1994) Importância da adubação na qualidade do feijão e caupi In: Sá ME, Buzzeti S Importância da adubação na qualidade dos produtos agrícolas. São Paulo. p.233-248.

Bonfante A, Terribile F, Bouma J (2019) Refining physical aspects of soil quality and soil health when exploring the effects of soil degradation and climate change on biomass production: an Italian case study. Soil. 5: 1-14.

Bonfim-Silva EM, Pacheco AB, Silva TJA, Santo ES, Bär CSLL, Souza HHF (2016) Biometric characteristics and visual diagnosis of safflower plants under macro and micronutrient omission. Int J Curr Res. 8 (5): 31071-31076.

Bonfim-Silva EM, Castro $H$, Rezende $P$, Favare $H$, Dourado LGA, Sousa HE, Silva TJA (2018) Wood Ash as a Corrective and Fertilizer in the Cultivation of Mombaça and Massai Grass in Oxisol. J Exp Agric Int. 21: 1-10.

Bonfim-silva EM, Pereira MTJ, Fontenelli JV, Gonçalves JM, Schlichting AF(2017) Wood Ash in Canavalia ensiformis L. Cultivation on Highly Weathered Soil in Brazil. Int J Plant Soil Sci. 16: 1-7.

Cairo PAR (1995) Curso básico de relações hídricas de plantas. Vitória da Conquista: UESB, p. 32.

Campo RJ, Hungria M (2002) Importância dos micronutrientes na fixação biológica do $\mathrm{N}^{2}$. Inf $\mathrm{Agr}$ Piracicaba. 98: 6-9.

Carneiro JGA (1995) Produção e controle de qualidade de mudas florestais. Curitiba: UFPR/FUPEF, p. 451.

Challinor AJ, Koehler AK, Ramirez-Villegas J, Whitfield S, Das B (2016) Current warming will reduce yields unless maize breeding and seed systems adapt immediately. Nat Clim Change. 6: 954-958.

Chaudhary MI, Fujita K (1998) Comparison of phosphorus deficiency effects on the growth parameters of mashbean, mungbean, and soybean. Soil Sci Plant Nutr. 44 (1): 19-30.

Conceição PC, Amado TJC, Mielniczuk J, Spagnollo E (2005) Qualidade do solo em sistemas de manejo avaliada pela dinâmica da matéria orgânica e atributos relacionados. $\mathrm{R}$ Bras Ci Solo. 29 (5): 777-788.

Costa KAP, Araújo JL, Faquin V, Oliveira IP, Figueiredo SC, Gomes KW (2008) Extração de macronutrientes pela fitomassa do capim-xaraés em função de doses de nitrogênio e potássio. R Ci Rural. 38 (4): 1162-1166.

Cruz-Paredes C, Wallander H, Kjøller R, Rousk J (2017) Using community trait-distributions to assign microbial responses to $\mathrm{pH}$ changes and $\mathrm{Cd}$ in forest soils treated with wood ash. Soil Biol Biochem. 112: 153-164.

Dallago JS (2000) Utilização da cinza de biomassa de caldeira como fonte de nutrientes no crescimento de plantas de acácia-negra (Acacia mearnsii DeWild.). 64 p. Dissertação (Mestrado em Engenharia Florestal), UFSM, Santa Maria.

Das S, Kar RK (2017) Abscisic acid mediated differential growth responses of root and shoot of Vigna radiata (L.) Wilczek seedlings under water stress. Plant Physiol Biochem. 123:213-221.

Donega MA, Volk LBS, Nolla A, Gaviolli TO (2011) Atributos químicos do solo e crescimento inicial de plantas de milho em Latossolo arenoso com adição de cinza de casca de arroz. Revista de Agricultura. 86 (3): 192-199.

Drew MC (1997) Oxygen deficiency and root metabolism: injury and acclimation under hypoxia and anoxia. Annu. Rev. Plant Physiol Plant Mol Biol. 48: 223-250.

Embrapa - Empresa Brasileira de Pesquisa Agropecuária (2017) Centro Nacional de Pesquisa de Solos. Manual de métodos de análises de solo. (3. Ed., p. 573) Brasília, DF: Embrapa.

Erich MS, Ohno T (1992) Titrimetric determination of calcium carbonate equivalence of wood ash. Analyst, 117: 993-995.

Etiégni L, Campbell AG (1991) Physical and chemical characteristics of wood ash. Bioresour Technol. 37: 173178.

Fageria NK, Barbosa Filho MP, Stone LF (2003) Resposta do feijoeiro a adubação fosfatada. In: POTAFÓS. Simpósio destaca a essencialidade do fósforo na agricultura brasileira. Inf Agr. 102: 1-9.

Ferreira DF (2011) Sisvar: Um sistema computacional de estatística. Cienc e Agrotec. 35: 1039-1042.

Floss EL (2004) Fisiologia das plantas cultivadas. Passo Fundo: UPF.

Foletto EL, Hoffmann R, Hoffmann RS, Portugal Júnior UL, Jahn SL (2005) Aplicabilidade das cinzas da casca de arroz. Quim. Nova. 28 (6): 1055-1060.

Freire M, Lopes H, Tarelho LAC (2015) Critical aspects of biomass ashes utilization in soils: Composition, leachability, PAH and PCDD/F. J Waste Manag. 46: 304315.

Freitas CAS, Silva ARA, Bezerra FML, Lacerda CF, PereiraFilho JV, Souza GG (2011) Produção de matéria seca e trocas gasosas em cultivares de mamoneira sob níveis de irrigação. Ver Bras Eng Agríc Ambient. 15: 1168-1174.

Grant CA, Platen DN, Tomaziewicz DJ, Sheppard SC (2001) A importância do fósforo no desenvolvimento inicial da planta. Inf Agr Piracicaba. p. 95.

Guimarães TG, Fontes PCR, Pereira PRG, Alvarez V VH, Monnerat PH (1999) Teores de clorofila determinados por medidor portátil e sua relação com formas de nitrogênio em folhas de tomateiro cultivado em dois tipos de solo. Bragantia. 58 (1): 209-216.

Hansen M, Kepfer-Rojas S, Bjerager PER, Holm PE, Skov S, Ingerslev M (2018) Effects of ash application on nutrient and heavy metal fluxes in the soil and soil solution in a Norway spruce plantation in Denmark. Forest Ecol Manag. 424: 494-504.

Holford ICR (1997) Soil phosphorus: its measurement, and its uptake by plants. Aust J Soil Res. 35: 227-239.

Ingerslev M, Hansen M, Pedersen LB, Skov S (2014) Effects of wood chip ash fertilization on soil chemistry in a Norway spruce plantation on a nutrient-poor soil. Forest Ecol Manag. 334: 10-17.

Inman-Bamber NG, Bonnett GD, Spillman MF, Hewitt ML, Jackson J (2008) Increasing sucrose accumulation in sugarcane by manipulating leaf extension and photosynthesis with irrigation. Aust J Agric Res. 59:13-26. 
Islabão GO, Lima CLR, Vahl LC, Timm LC, Teixeira JBS (2016) Hydro-Physical Properties of a Typic Hapludult under the Effect of Rice. Ver Bras Cienc Solo. 40 (1): 1-13.

Karmakar S, Mittra BN, Ghosh BC (2010) Enriched Coal Ash Utilization for Augmenting Production of Rice under Acid Lateritic Soil. Coal Combust. Gasificat Produc. 2: 45-50.

Kumar P, Pal M, Joshi R, Sairam RK (2013) Yield, growth and physiological responses of mung bean [Vigna radiata (L.) Wilczek] genotypes to waterlogging at vegetative stage. Physiol Mol Biol Plants. 19:209-220.

Larcher W (2004) Ecofisiologia vegetal. São Carlos: RiMa. pp. 531.

Littell RC, Mott GO (1975) Computer assisted design and analysis of response surface experiments in agronomy. Soil Crop Societ. Florida Proceed. 34: 94-97.

Ludlow MM, Muchow RC (1990) A critical evaluation of traits for improving crop yields in water-limited environments. Adv Agron. 43: 107-153.

Mahajan S, Tuteja NC (2005) Salinity and drought stresses:An overview. Arch. Bioch. Biophys., 444: 139-158.

Malavolta E, Vitti GC, Oliveira AS (1989) Avaliação do estado nutricional das plantas: princípios e aplicações. Piracicaba: Associação Brasileira para Pesquisa da Potassa e do Fosfato, p. 201

Maresca A, Hyks J, Astrup TF (2017) Recirculation of biomass ashes onto forest soils: ash composition, mineralogy and leaching properties. J Waste Manag. 70: 127-138.

Markwell J, Osterman JC, Mitchell JL (1995) Calibration of the Minolta SPAD-502 leaf chlorophyll meter. Photosynth Res. 46 (3): 467-472.

Murphy HE, Edwards DG, Asher CJ (1984) Effects of aluminium on nodulation and early growth of four tropical pasture legumes. Aust J Agric. Res. 35: 663-673.

Nezami A, Khazaei HR, Boroumand RZ, Hosseini A (2008) Effects of drought stress and defoliation on sunflower (Helianthus annuus L.) in controlled conditions. Desert. 1: 99-104.

Nogueira RJMC, Albuquerque MB, Silva EC (2005) Aspectos ecofisiológicos da tolerância à seca em plantas da caatinga. In: Nogueira RJMC et al. Estresses ambientais: danos e benefícios em plantas. Recife: Universidade Federal de Pernambuco, p. 22-31.

Ohno T (1992) Neutralization of soil acidity and release of phosphorus and K by wood ash. J Environ Qual. 21: 433438.

Pandey P, Irulappan V, Bagavathiannan MV, Senthil-Kumar M (2017) Impact of combined abiotic and biotic stresses on plant growth and avenues for crop improvement by exploiting physio-morphological traits. Front Plant Sci. 8: 537.

Pantano G, Grosseli GM, Mozeto AA, Fadini P (2016) Sustentabilidade do uso do fósforo: Uma questão de segurança hídrica e alimentar. Quim Nova. 39 (6): 732-740.

Park ND, Rutherford PM, Thring RW, Helle SS (2012) Wood pellet fly ash and bottom ash as an effective liming agent and nutriente source for rye grass (Lolium perenne L.) and oats (Avena sativa). Chemosphere. 86: 427-432.

Pereira MTJ, Silva TJA, Bonfim-Silva EM, Mazzini-Guedes RB (2016) Applying wood ash and soil moisture on gladiolus (Gladiolus grandiflorus) cultivation. Aust J Crop Sci. 10 (3): 393-401.

Pinheiro EAR, Jong VQ, Šimůnek J (2019) The role of soil hydraulic properties in crop water use efficiency: A process-based analysis for some Brazilian scenarios. Agric Syst. 173: 364-377.
Prado RM, Correa MCM, Pereira L, Cintra ACO, Natale W (2002) Efeito da cinza de indústria de cerâmica no solo e na nutrição de mudas de goiabeira. Acta Sci Agron. 24: 1493-1500.

Rada N (2013) Assessing Brazil's Cerrado agricultural miracle. Food Policy. 38:146-155.

Ram LC, Masto RE (2014) Fly ash for soil amelioration: A review on the influence of ash blending with inorganic and organic amendments. Earth-Sci Rev. 128: 52-74.

Ray DK, Mueller ND, West PC, Foley JA (2013) Yield Trends Are Insufficient to Double Global Crop Production by 2050. PLoS ONE. 8(6): 66428.

Sa TM, Israel DW (1991) Energy status and functioning of phosphorus-deficient soybean nodules. Plant Physiol. 97: 928-935.

Sangakkara UR, Frehner M, Nosberger J (1999) Effect of Soil Moisture and Potassium Fertilizer on Shoot Water Potential\ Photosynthesis and Partitioning of Carbon in Mungbean and Cowpea. J Agron Crop Sci. 185: 201-207.

Santos CC, Bonfim-Silva EM, Silva TJA (2014) Tropical grass fertilized with wood ash in Cerrado Oxisol: Concentrations of calcium, magnesium and sulphur. Afr J Agric Res. 9 (19): 1495-1501.

Schlichting AF, Bonfim-Silva EM, Silva MC, Pietro-Souza W, Silva TJA, Farias LN (2015) Efficiency of portable chlorophyll meters in assessing the nutritional status of wheat plants. Braz J Agric Env Eng. 19 (12): 1148-1151.

Sengupta D, Guha A, Reddy AR (2013) Interdependence of plant water status with photosynthetic performance and root defense responses in Vigna radiata (L.) Wilczek under progressive drought stress and recovery. J Photoch Photobio B. 127: 170-181.

Silva IFL, Araújo ASF, Santos VB, Nunes LAP, Carneiro RFV (2010) Fixação biológica do $\mathrm{N}^{2}$ em feijão-caupi sob diferentes doses e fontes de fósforo solúvel. Biosci J. Uberlândia. 26 (3): 394-402.

Stoof CR, Wesseling JG, Ritsema CJ (2010) Effects of fire and ash on soil water retention. Geoderma. 159: 276-285.

Symanowicz B, Becher M, Jaremko D, Skwarek K (2018) Possibilities for the use of wood ashes in agriculture. J Ecol Eng. 19 (3): 191-196.

Strassburg BBN, Latawiec AE, Barioni LG, Nobre CA, Silva VP, Valentim JF, Vianna M, Assad ED (2014) When enough should be enough: improving the use of current agricultural lands could meet production demands and spare natural habitats in Brazil. Glob Environ Change. 28: 84-97.

Zhao C, Liu B, Piao S, Wang $X$, Lobell DB, Huang $Y$, Huang $M$, Yao $Y$, Bassu S, Ciais P, Durand J, Elliott J, Ewert F, Janssens IA, Li T, Lin E, Liu Q, Matrte P, Muller C, Peñuelas J, Ruane AC, Wallach D, Wang T, Wu D, Liu Z, Zhu Y, Zhu Z, Asseng S (2017) Temperature increase reduces global yields of major crops in four independent estimates. Proc Natl Acad Sci. 114: 9326-9331.

Zimmermann S, Frey B (2002) Soil respiration and microbial properties in an acid forest soil: effects of wood ash. Soil Biol Biochem. 34: 1727-1737. 